\title{
FREQUENCY OF OCCURRENCE OF METABOLIC SYNDROME RISK FACTORS IN CHILDREN AND ADOLESCENTS FROM THE CITY OF WROCLAW AND SURROUNDINGS*
}

\author{
Ewa Piotrowska ${ }^{1}$,Danuta Figurska-Ciura ${ }^{1}$, Karolina Łoźna ${ }^{1}$, Maciej Bienkiewiczz', Dominika Mazurek ${ }^{l}$, \\ Joanna Wyka ${ }^{1}$, Marcelina Węiel ${ }^{1}$, Jadwiga Biernat ${ }^{l}$, Michaela Godyla-Jabłoński ${ }^{I}$ \\ ${ }^{1}$ Department of Human Nutrition, Faculty of Food Sciences, Wrocław University of Life Sciences, \\ Wrocław, Poland
}

\begin{abstract}
Background. A recently growing number of children and adolescents with overweight or obesity is indicative of the need for diagnosing their complications that may appear in the early childhood. For this reason, diagnostic criteria were developed for components of the metabolic syndrome (MS) also for these groups of the population.

Objective. This study was aimed at evaluating the frequency of metabolic syndrome risk factors occurrence in children and adolescents from the city of Wrocław and surroundings depending on gender, age and physical activity.

Material and methods. Investigations on the frequency of occurrence of dietary and non-dietary risk factors of the metabolic syndrome were carried out in the years 2010-2017 among 771 children and adolescents aged 10-18 year, attending to primary schools, gymnasiums and secondary schools in Wrocław.

Results. The lack of any components of the metabolic syndrome was demonstrated in $14.78 \%$ of the children aged $10-12$ years as well as in $17.38 \%$ of both adolescents aged 13-15 and 17-18 years. One risk factor was most frequently diagnosed in children aged 10-12 years (17.89\%) and it was arterial hypertension (16.08\% of the whole surveyed population). Three MS components were demonstrated in 15 persons (1.95\% of the whole surveyed population), including in 7 girls and 8 boys. The persons with three MS risk factors from the age category $13-15$ years constituted $0.26 \%$ whereas these from the age category $17-18$ years constituted $1.69 \%$ of the whole surveyed group.

Conclusions. It shall be concluded that the incidence of the fully symptomatic MS depended significantly on the age of the surveyed, but not on their gender. Among the three adopted components of MS, the most frequently demonstrated disorders included: arterial hypertension, abdominal obesity and increased concentration of triglycerides in blood serum.
\end{abstract}

Keywords: children, adolescents, metabolic syndrome, risk factors

\section{STRESZCZENIE}

Wprowadzenie. Ostatnio rosnąca liczba dzieci i młodzieży z nadwagą lub otyłością wskazuje na potrzebę zdiagnozowania ich powikłań, które mogą pojawić się we wczesnym dzieciństwie. Z tego powodu opracowano kryteria diagnostyczne dla składników zespołu metabolicznego (ZM), również dla tych grup populacji.

Cel. Badanie to miało na celu ocenę częstotliwości występowania czynników ryzyka zespołu metabolicznego u dzieci i młodzieży z Wrocławia i okolic w zależności od płci, wieku i aktywności fizycznej.

Material i metody. W latach 2010-2017 przeprowadzono badania dotyczące częstości występowania dietetycznych i nie dietetycznych czynników ryzyka zespołu metabolicznego wśród 771 dzieci i młodzieży w wieku 10-18 lat, uczęszczających do szkół podstawowych, gimnazjów i szkół średnich szkoły we Wrocławiu.

Wyniki. Brak jakichkolwiek składników zespołu metabolicznego wykazano u 14,78\% dzieci w wieku 10-12 lat, a także u 17,38\% obu nastolatków w wieku 13-15 lat i 17-18 lat. Jeden czynnik ryzyka najczęściej diagnozowano u dzieci w wieku 10-12 lat $(17,89 \%)$ i było to nadciśnienie tętnicze (16,08\% całej badanej populacji). Trzy składniki ZM wykazano u 15 osób (1,95\% całej badanej populacji), w tym u 7 dziewcząt i 8 chłopców. Osoby z trzema czynnikami ryzyka ZM z kategorii wiekowej 13-15 lat stanowiły 0,26\%, zaś osoby z kategorii wiekowej 17-18 lat stanowiły 1,69\% całej badanej grupy.

Corresponding author: Michaela Godyla-Jabłoński, Uniwersytet Przyrodniczy we Wrocławiu, Wydział Biotechnologii i Nauk o Żywności, Katedra Żywienia Człowieka, ul. Chełmońskiego 37, 51-630 Wrocław, Poland, tel.: +48 884734 030, e-mail: michaela.godyla@upwr.edu.pl

*) The study was conducted under the Polish Scientific Research Committee (KBN) grant no. 312183438 entitled "Evaluation of the frequency of occurrence of dietary and non-dietary risk factors of the metabolic syndrome in girls and boys at various stages of their pubescence". 
Wnioski. Należy stwierdzić, że częstość występowania w pełni objawowego ZM zależała w znacznym stopniu od wieku badanych, ale nie od ich płci. Wśród trzech przyjętych składników ZM najczęściej wykazanymi zaburzeniami były: nadciśnienie tętnicze, otyłość brzuszna i zwiększone stężenie triglicerydów w surowicy krwi.

Słowa kluczowe: dzieci, młodzież, zespół metaboliczny, czynniki ryzyka

\section{INTRODUCTION}

The metabolic syndrome (MS) was defined for adults in 2005 as the co-occurrence of such ailments as: abdominal obesity (waist circumference $\geq 94 \mathrm{~cm}$ in the European men and $\geq 80 \mathrm{~cm}$ in the European women), increased serum level of triglycerides ( $\geq 150$ $\mathrm{mg} / \mathrm{dl}$ ) or treatment of hypertriglyceridemia, reduced concentration of HDL cholesterol fraction $(<40 \mathrm{mg} / \mathrm{dl}$ in men and $<50 \mathrm{mg} / \mathrm{dl}$ in women) or treatment of dyslipidemia, increased blood pressure (systolic $\geq 130 \mathrm{~mm}$ $\mathrm{Hg}$, diastolic $\geq 85 \mathrm{mmHg}$ ) or treatment of the earlier diagnosed arterial hypertension, increased fasting glucose blood level ( $\geq 100 \mathrm{mg} / \mathrm{dl}$ ) or earlier diagnosed type 2 diabetes [1]. A continuously growing number of children and adolescents with overweight and obesity has prompted experts to develop diagnostic criteria of components of the metabolic syndrome also for these populations. It has become indispensable to refer threshold values of particular MS criteria to standards respective to age, and to consider the specific homeostasis and hormonal metabolism in the pubescence, e.g. physiological insulin resistance [15]. Currently valid are standardized guidelines for MS diagnostics that were elaborated in 2007 by the International Diabetes Federation (IDF) for three age categories: 6-9 years, 10-16 years, and over 16 years. They are presented in Table 1 [22].

Table 1. Definition and criteria of diagnosis of the metabolic syndrome (MS) in children according to International Diabetes Federation (IDF) [3]

\begin{tabular}{|c|c|c|c|c|c|}
\hline Age group & $\begin{array}{c}\text { Waist } \\
\text { circumference }\end{array}$ & Triglycerides & $\mathrm{HDL}$ - Ch & $\begin{array}{c}\text { Arterial blood } \\
\text { pressure }\end{array}$ & Glycaemia \\
\hline $6-10$ years & $\geq 90$ th percentile & \multicolumn{4}{|c|}{$\begin{array}{l}\text { MS cannot be diagnosed, but further measurements should be made if there } \\
\text { is a family history of metabolic syndrome, type } 2 \text { diabetes, dyslipidemia, } \\
\text { cardiovascular diseases, arterial hypertension and/or obesity }\end{array}$} \\
\hline $10-16$ years & $\begin{array}{l}\geq 90 \text { th percentile } \\
\text { or adult cut-off if } \\
\text { lower }\end{array}$ & $\begin{array}{l}\geq 150 \mathrm{mg} / \mathrm{dl} \\
(\geq 1.7 \mathrm{mmol} / \mathrm{l})\end{array}$ & $\begin{array}{l}<40 \mathrm{mg} / \mathrm{l} \\
(<1.03 \mathrm{~mol} / \mathrm{l})\end{array}$ & $\begin{array}{l}\text { Systolic } \\
\geq 130 \mathrm{mmHg} \text { and/or } \\
\text { diastolic } \geq 85 \mathrm{mmHg}\end{array}$ & $\begin{array}{l}\geq 100 \mathrm{mg} / \mathrm{dl} \\
(>5.6 \mathrm{mmol} / \mathrm{l}) \\
\text { or diagnosed type } \\
2 \text { diabetes }\end{array}$ \\
\hline$>16$ years & \multicolumn{5}{|c|}{$\begin{array}{l}\text { Use existing IDF criteria for adults, i.e.: } \\
-\quad \text { central obesity (defined as waist circumference } \geq 94 \mathrm{~cm} \text { for European men and } \geq 80 \mathrm{~cm} \text { for } \\
\text { European women) } \\
\text { plus any two of the following four factors: } \\
-\quad \text { raised triglycerides: } \geq 150 \mathrm{mg} / \mathrm{dl}(1.7 \mathrm{mmol} / \mathrm{l}) \text { or specific treatment of these lipid } \\
\text { abnormalities } \\
-\quad \text { reduced HDL-cholesterol: }<40 \mathrm{mg} / \mathrm{dl}(1.03 \mathrm{mmol} / \mathrm{l}) \text { in males and }<50 \mathrm{mg} / \mathrm{dl}(1.29 \mathrm{mmol} / \mathrm{l}) \\
\quad \text { in females, or specific treatment for these lipid abnormalities } \\
-\quad \text { raised blood pressure: systolic } \mathrm{BP} \geq 130 \text { or diastolic } \mathrm{BP} \geq 85 \mathrm{~mm} \mathrm{Hg} \text {, or treatment of } \\
\text { previously diagnosed hypertension } \\
\text { increased fasting glycaemia: } \geq 100 \mathrm{mg} / \mathrm{dl}(5.6 \mathrm{mmol} / \mathrm{l}) \text { or previously diagnosed type } 2 \\
\text { diabetes }\end{array}$} \\
\hline
\end{tabular}

Among children and adolescents aged 10-16 years, the metabolic syndrome is diagnosed based on the occurrence of abdominal obesity and two or more ailments like: hyperglycemia, hypertriglyceridemia or arterial hypertension. Overweight and obesity appearing as early as in child pubescence may lead to the development of other metabolic disorders. Together with low physical activity and improper eating habits, they are mainly responsible for the development of insulin resistance and dyslipidemia. The connection between disorders of lipids metabolism, carbohydrate metabolism, arterial hypertension and visceral obesity has been undisputedly proved in the population of adults. Experimental results point also to a strict correlation between the occurrence of risk factors and MS components in the early period of life with the fullysymptomatic picture of this syndrome in the adult life $[14,20]$.

Early diagnosis of MS components or fully-symptomatic MS in children and adolescents enables early implementation of the principles of prophylaxis or therapy, which enables effective reduction of the risk 
of the development of another metabolic abnormalities and mortality of these in the adult age. In epidemiological surveys conducted among children and adolescent, of key significance is detection of the incidence of such ailments as: simple obesity, abdominal obesity, insulin resistance, arterial hypertension, as well as incriminating family history [2]. In studies on the incidence of the metabolic syndrome in children and adolescents, authors have adopted very diversified diagnostic criteria, which have resulted in many divergent estimates of the number of children affected with this syndrome. Results of surveys conducted in many countries demonstrated that the fully symptomatic MS is diagnosed more often in groups of young obese persons, but it is also reported in adolescents without overweight nor obesity. In groups of young people with obesity, the frequency of MS diagnosis reaches even $30 \%$ of the subjects $[10,16]$. Various diagnostic criteria were applied and thus significantly different results were achieved also in Polish studies on the incidence of MS in children and adolescents. They, however, demonstrated that the fully-symptomatic MS referred to over $10 \%$ of the surveyed with diagnosed obesity $[3,18]$.

This study was aimed at evaluating the frequency of occurrence of metabolic syndrome risk factors in children and adolescents from the city of Wrockaw and surroundings depending on gender, age and physical activity, based on the evaluation of their nutritional status.

\section{MATERIAL AND METHODS}

\section{Characteristics of the studied population}

Investigations on the frequency of occurrence of dietary and non-dietary risk factors of the metabolic syndrome were carried out in 2010-2017 among children and adolescents aged 10-18 years, attending primary schools, gymnasiums and secondary schools in the city of Wrocław. The adopted risk factors of the metabolic syndrome (MS) in children and adolescents included the occurrence of: obesity (especially the abdominal one), increased parameters of lipid metabolism (triglycerides in particular), increased blood pressure and increased glucose concentration. The physical activity of the surveyed was evaluated based on results of an interview that included questions related to physical activities undertaken at school and after school.

The selection of schools for the survey was intention$\mathrm{al}$, and the main qualification criterion was participation in the "School promoting health" program. In 3 primary schools, the survey was conducted in all 4th grade and 5 th grade classes, whereas in 3 gymnasium and 3 secondary schools - in all 1st grade and 2nd grade classes. Over 900 children were selected in total for the study, however all stages of the survey were completed by a group of 771 schoolchildren. The survey was conducted in the morning hours, during the first lesson, upon a consent of a leading teacher. Before the study, each child provided a written consent of parents or in older groups - their own consent for participation in all stages of the study including analyses of: nutritional pattern and eating behaviors, knowledge regarding risk factors of civilization diseases, socio-demographic conditions, anthropometric traits, and selected biochemical blood parameters. The study was approved by the Bioethics Commission at the Medical University in Wrocław (approval no. KB - 376/2009).

Study inclusion criteria were as follows: appropriate age, lack of chronic diseases, written consent of the surveyed or parents, and participation in all stages of the study. Exclusion from the study occurred in a subject failed to meet the conditions of participation in the project.

The age category of 17-18 years was constituted by 269 adolescents, including 160 girls and 109 boys. In gymnasiums, the survey covered 232 pupils aged 1315 years (129 girls and 103 boys), whereas in primary schools it was conducted among 270 children aged 1012 years (133 girls and 137 boys). The total surveyed group counted 771 pupils. In all age categories of children and adolescents there were more girls (54.7\%) than boys $(45.3 \%)$. The highest number of children and adolescents lived in the city of Wrocław - 613 persons $(82.5 \%)$, whereas 130 persons $(17.5 \%)$ lived outside Wrockaw and were commuting to schools. Among the commuting persons, the greatest group was represented by adolescents aged $17-18$ years $(56.2 \%)$, whereas the smallest group - by children attending to gymnasiums $(14.6 \%)$. Most of the surveyed (77.8\%) originated from complete families, including: $38 \%$ of children aged $10-12$ years, $29.5 \%$ of the surveyed aged $13-15$ years, and $32.5 \%$ of adolescents aged $17-18$ years, whereas $22.2 \%$ of the children and adolescents were raising in incomplete families. Furthermore, $28.1 \%$ of children and adolescents originated from families in which both parents had higher education, whereas $18.4 \%$ of the surveyed came from families in which at least one of the parents had higher education. The remaining $53.5 \%$ of the surveyed were from families in which parents had: primary, occupational or secondary education.

In the whole studied group - $57.5 \%$ of the persons declared medium physical activity. In turn, high physical activity was declared by $42.5 \%$ of girls and boys. In the case of adolescents attending secondary schools, there were no persons with declared high physical activity and ca. $20 \%$ of these adolescents declared to have permanent exemption form physical education classes.

The largest groups of the surveyed $(78.2 \%)$ was represented by young persons with normal values of the body mass index (BMI at 5-85pc.). Overweight was demonstrated in $11.3 \%$ of girls and boys (BMI 85 $95 \mathrm{pc}$.), whereas obesity - in 7\% of the surveyed (BMI exceeding 95pc). BMI values below 5pc. - indicative of body mass deficiency and malnutrition, were demonstrated in $3 \%$ of the surveyed (Table 2 ). 
Table 2. Characteristics of the surveyed group of children and adolescents considering values of the body mass index $(\mathrm{BMI})(\mathrm{n}=771)$

\begin{tabular}{|c|c|c|c|c|c|c|c|}
\hline \multirow{2}{*}{$\begin{array}{l}\text { Age group } \\
\text { BMI } \\
\text { (percentiles) }\end{array}$} & \multicolumn{2}{|c|}{$\begin{array}{c}10-12 \text { years } \\
n=270\end{array}$} & \multicolumn{2}{|c|}{$\begin{array}{c}13-15 \text { years } \\
n=232\end{array}$} & \multicolumn{2}{|c|}{$\begin{array}{c}17-18 \text { years } \\
n=269\end{array}$} & \multirow{2}{*}{$\begin{array}{c}\text { Total } \\
\mathrm{n}=771 \\
\% \text { of the studied group }\end{array}$} \\
\hline & $\mathrm{n}$ & $\%$ & $\mathrm{n}$ & $\%$ & $\mathrm{n}$ & $\%$ & \\
\hline$<5 \mathrm{pc}$ & 6 & 2.2 & 7 & 3.0 & 14 & 5.2 & 3.5 \\
\hline $5-85 \mathrm{pc}$ & 226 & 83.7 & 188 & 81.0 & 189 & 70.2 & 78.2 \\
\hline $85-95 \mathrm{pc}$ & 29 & 10.7 & 25 & 10.8 & 33 & 12.3 & 11.3 \\
\hline$>95 \mathrm{pc}$ & 9 & 3.3 & 12 & 5.2 & 33 & 12.3 & 7.0 \\
\hline $\begin{array}{c}\text { Total } \\
\% \text { of the studied group }\end{array}$ & \multicolumn{2}{|c|}{35.0} & \multicolumn{2}{|c|}{30.1} & \multicolumn{2}{|c|}{34.9} & 100.0 \\
\hline
\end{tabular}

\section{Analytical methods}

Basic anthropometric parameters: body height and body mass, waist circumference and hip circumference, were measured in all groups of the surveyed children and adolescents. The measurements were taken of pupils wearing light clothes or sports suit, and shoeless. Values obtained were compared with centile charts elaborated in the framework of the nation-wide research project OLAF [12].

Body height and body mass were measured using a medical scale equipped in a stadiometer with the accuracy of: $0.1 \mathrm{~cm}$ (body height) and $0.1 \mathrm{~kg}$ (body mass). The correct values fitted within the range of 5 to $95 \mathrm{pc}$. Accordingly to the adopted ranges, values below 5 pc indicated deficient body mass, and values exceeding $95 \mathrm{pc}$ were indicative of overweight and obesity, whereas in the case of body height - were indicative of short and tall stature, respectively [13].

Waist and hip circumference were measured using an anthropometric tape with the accuracy of $0.1 \mathrm{~cm}$, respectively at the height of the belly button and below the iliac ala. Normal values were in the range of 5-95 pc. Abdominal obesity was diagnosed at waist circumference $\geq 95 \mathrm{pc}$.

Values of body height and body mass were further used to calculate the body mass index (BMI). According to centile charts, the resultant values were grouped as follows: $<5 \mathrm{pc}$ - underweight; 5-85 pc - normal body mass; $85-95 \mathrm{pc}$ - overweight; and $\geq 95 \mathrm{pc}$ - obesity.

Arterial blood pressure was measured with the $\mathrm{Ko}$ rotkow's auscultators method, using a monometer and a stethoscope [21].

Blood samples for biochemical analyses were collected by a qualified worker of an analytical laboratory from the elbow vein, from fasted subjects, in the morning hours. Assays of concentrations of biochemical parameters were conducted with standard methods in blood serum and included: total cholesterol, HDL and LDL fractions of cholesterol, triglycerides and glucose. These analyses were conducted in the groups of the surveyed attending gymnasiums and secondary schools. They were not carried out in children from primary schools because of lack of the consent of most of the parents.

\section{Statistical analysis of results}

Results of anthropometric measurements and biochemical analyses were processed in Statistica 10.0 PL software (StatSoft Inc. USA+). The Shapiro-Wilk's test was used to check the consistence of the results with normal distribution in the entire studied group, in age categories, in gender groups as well as in other groups depending on the grouping variable. The Levene's (ANOVA) test was applied to check the variance homogeneity. In order to characterize the studied group of children and adolescents: median (Me), minimum (Min) and maximum (Max) values, as well as the bottom and upper quartile $\left(\mathrm{Q}_{1} ; \mathrm{Q}_{3}\right)$ were calculated in each group. Most of the results of biochemical analyses and anthropometric measurements were characterized by high variability, were inconsistent with normal distribution and had no homogenous variances. Considering the above, the Box-Cox transformation was applied which enabled adjusting the system of data to normal distribution. Differences between mean values of anthropometric and biochemical parameters in the analyzed population of children and adolescents divided into groups according to gender, age or a grouping variable were evaluated with the one-way analysis of variance using Tukey's test (ANOVA). Multi-way tables and $C h i^{2}$ test were used for comparison and for determination of the significance of differences in groups according to age, nutritional status, and selected factors of lifestyle of children and adolescents, and the frequency of occurrence of risk factors of the metabolic syndrome.

\section{RESULTS}

Table 3 presents the frequency of occurrence and concurrence of the components of the metabolic syndrome in the surveyed groups of children and adolescents. According to IDF 2007 definition [18] and centile charts for the Polish population [4], the risk factors of MS development included: waist circumference $\geq 94$ $\mathrm{cm}$ (boys) and $\geq 80 \mathrm{~cm}$ (girls) $(\geq 95 \mathrm{pc})$, increased concentration of triglycerides $\geq 130 \mathrm{mg} / \mathrm{dl}$, decreased concentration of HDL cholesterol fraction $\leq 40 \mathrm{mg} / \mathrm{dl}$, increased value of arterial blood pressure $\geq 130 / 85 \mathrm{~mm} \mathrm{Hg}$ ( $\geq 90 \mathrm{pc}$ ), and incorrect fasting glycaemia $\geq 100 \mathrm{mg} / \mathrm{dl}$. 


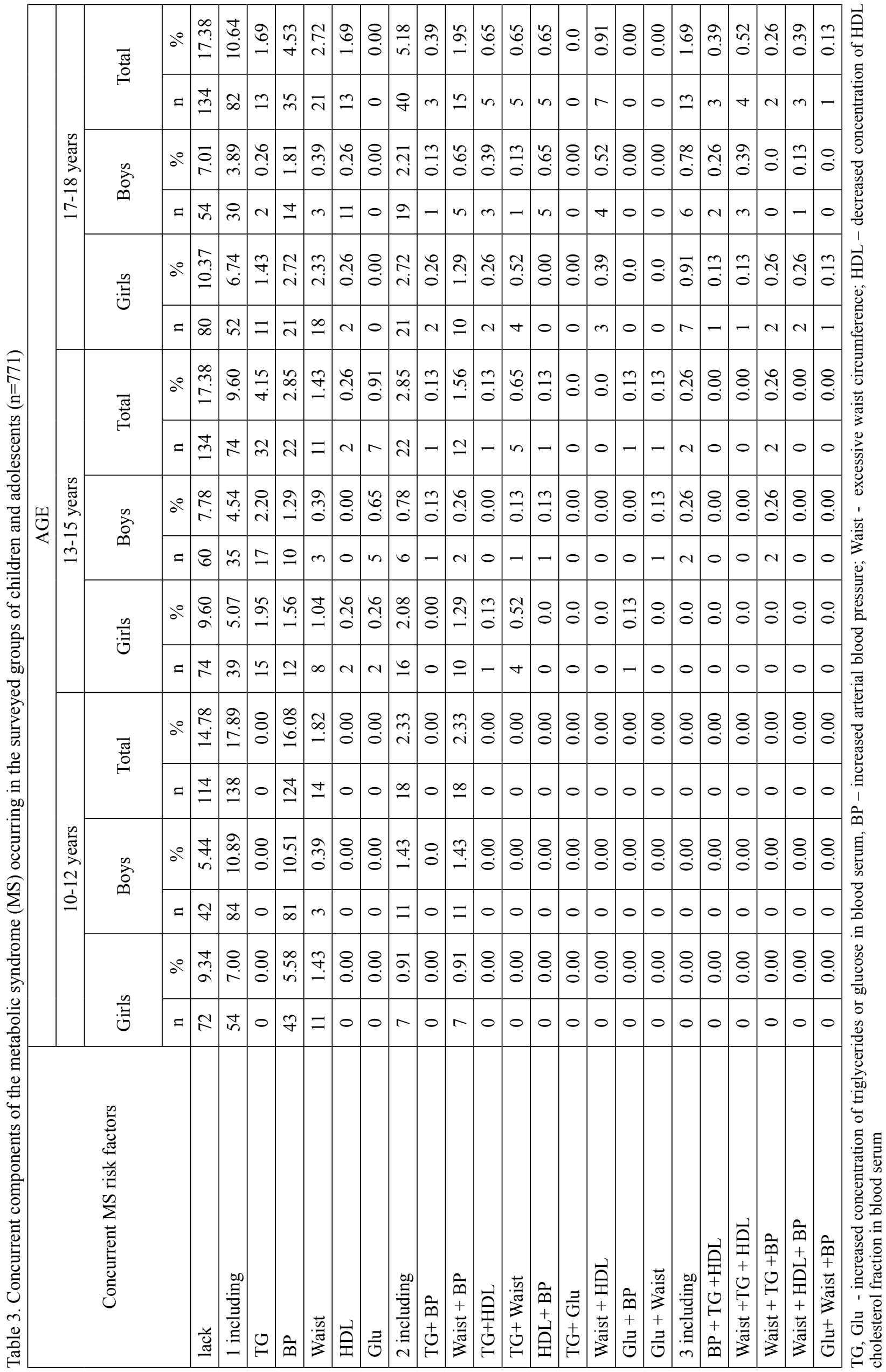


Table 4. Frequency of occurrence of metabolic syndrome components in the surveyed groups $(n=771)$ depending on age

\begin{tabular}{|c|c|c|c|c|c|c|c|c|c|c|c|}
\hline \multirow{3}{*}{ Gender } & \multirow{3}{*}{ Age category } & \multirow{3}{*}{ Age } & \multicolumn{8}{|c|}{ Number of components of the metabolic syndrome } & \multirow{3}{*}{$\mathrm{P}$} \\
\hline & & & \multicolumn{2}{|c|}{0} & \multicolumn{2}{|c|}{1} & \multicolumn{2}{|c|}{2} & \multicolumn{2}{|c|}{3} & \\
\hline & & & $\mathrm{n}$ & $\%$ & $\mathrm{n}$ & $\%$ & $\mathrm{n}$ & $\%$ & $\mathrm{n}$ & $\%$ & \\
\hline \multirow{12}{*}{$\begin{array}{c}\text { Girls } \\
(n=422)\end{array}$} & \multirow{4}{*}{$\begin{array}{l}10-12 \text { years } \\
(n=133)\end{array}$} & 10 years & 6 & 0.79 & 10 & 1.29 & 2 & 0.26 & 0 & 0.00 & \multirow{12}{*}{0.001} \\
\hline & & 11 years & 28 & 3.63 & 21 & 2.72 & 2 & 0.26 & 0 & 0.00 & \\
\hline & & 12 years & 38 & 4.92 & 23 & 2.99 & 3 & 0.39 & 0 & 0.00 & \\
\hline & & Total & 72 & 9.34 & 54 & 7.00 & 7 & 0.91 & 0 & 0.00 & \\
\hline & \multirow{4}{*}{$\begin{array}{l}13-15 \text { years } \\
(n=129)\end{array}$} & 13 years & 18 & 2.33 & 15 & 1.95 & 4 & 0.52 & 0 & 0.00 & \\
\hline & & 14 years & 33 & 4.28 & 15 & 1.95 & 9 & 1.17 & 0 & 0.00 & \\
\hline & & 15 years & 23 & 2.99 & 9 & 1.17 & 3 & 0.39 & 0 & 0.00 & \\
\hline & & Total & 74 & 9.60 & 39 & 5.07 & 16 & 2.08 & 0 & 0.00 & \\
\hline & \multirow{3}{*}{$\begin{array}{c}\text { 17-18 years } \\
(n=160)\end{array}$} & 17 years & 44 & 5.71 & 15 & 1.95 & 9 & 1.17 & 2 & 0.26 & \\
\hline & & 18 years & 36 & 4.66 & 37 & 4.79 & 12 & 1.56 & 5 & 0.65 & \\
\hline & & Total & 80 & 10.37 & 52 & 6.74 & 21 & 2.72 & 7 & 0.91 & \\
\hline & Girls in total & & 226 & 29.31 & 145 & 18.81 & 44 & 5.71 & 7 & 0.91 & \\
\hline \multirow{12}{*}{$\begin{array}{c}\text { Boys } \\
(n=349)\end{array}$} & \multirow{4}{*}{$\begin{array}{c}10-12 \text { years } \\
(n=137)\end{array}$} & 10 years & 1 & 0.13 & 4 & 0.52 & 1 & 0.13 & 0 & 0.00 & \multirow{12}{*}{$<0.00001$} \\
\hline & & 11 years & 21 & 2.71 & 25 & 3.24 & 3 & 0.39 & 0 & 0.00 & \\
\hline & & 12 years & 20 & 2.59 & 55 & 7.13 & 7 & 0.91 & 0 & 0.00 & \\
\hline & & Total & 42 & 5.44 & 84 & 10.89 & 11 & 1.43 & 0 & 0.00 & \\
\hline & \multirow{7}{*}{$\begin{array}{l}\text { 17-18 years } \\
(n=109)\end{array}$} & 13 years & 22 & 2.85 & 1 & 0.13 & 2 & 0.26 & 0 & 0.00 & \\
\hline & & 14 years & 27 & 3.50 & 18 & 2.33 & 3 & 0.39 & 1 & 0.13 & \\
\hline & & 15 years & 11 & 1.43 & 16 & 2.08 & 1 & 0.13 & 1 & 0.13 & \\
\hline & & Total & 60 & 7.78 & 35 & 4.54 & 6 & 0.78 & 2 & 0.26 & \\
\hline & & 17 years & 26 & 3.37 & 16 & 2.08 & 9 & 1.17 & 2 & 0.26 & \\
\hline & & 18 years & 28 & 3.64 & 14 & 1.81 & 10 & 1.29 & 4 & 0.52 & \\
\hline & & Total & 54 & 7.01 & 30 & 3.89 & 19 & 2.21 & 6 & 0.78 & \\
\hline & Boys in total & & 156 & 20.23 & 149 & 19.32 & 36 & 4.67 & 8 & 1.04 & \\
\hline \multirow{12}{*}{$\begin{array}{c}\text { Total } \\
(\mathrm{n}=771)\end{array}$} & \multirow{4}{*}{$\begin{array}{l}10-12 \text { years } \\
(n=270)\end{array}$} & 10 years & 7 & 0.92 & 14 & 1.81 & 3 & 0.39 & 0 & 0.00 & \multirow{12}{*}{$<0.00001$} \\
\hline & & 11 years & 49 & 6.34 & 46 & 5.96 & 5 & 0.65 & 0 & 0.00 & \\
\hline & & 12 years & 58 & 751 & 78 & 10.12 & 10 & 1.29 & 0 & 0.00 & \\
\hline & & Total & 114 & 14.78 & 138 & 17.89 & 18 & 2.34 & 0 & 0.00 & \\
\hline & \multirow{4}{*}{$\begin{array}{c}13-15 \text { years } \\
(n=232)\end{array}$} & 13 years & 40 & 5.18 & 25 & 2.08 & 6 & 0.78 & 0 & 0.00 & \\
\hline & & 14 years & 60 & 6.49 & 33 & 4.28 & 12 & 1.56 & 1 & 0.13 & \\
\hline & & 15 years & 34 & 4.42 & 16 & 3.25 & 4 & 0.52 & 1 & 0.13 & \\
\hline & & Total & 134 & 17.38 & 74 & 9.60 & 22 & 2.85 & 2 & 0.26 & \\
\hline & \multirow{3}{*}{$\begin{array}{l}17-18 \text { years } \\
(n=269)\end{array}$} & 17 years & 70 & 9.08 & 31 & 4.02 & 18 & 2.33 & 4 & 0.52 & \\
\hline & & 18 years & 64 & 8.30 & 51 & 6.62 & 22 & 2.85 & 9 & 1.17 & \\
\hline & & Total & 134 & 17.38 & 82 & 10.64 & 40 & 5.18 & 13 & 1.69 & \\
\hline & Whole group & & 382 & 49.54 & 294 & 38.13 & 80 & 10.37 & 15 & 1.95 & \\
\hline
\end{tabular}

$\mathrm{p}<0.05$ - the level of significance of $\mathrm{chi}^{2}$ test used to compare the frequency of occurrence of metabolic syndrome components in groups of boys and girls depending on age

The age categories of children and adolescents were divided into 3 sub-groups considering the number of occurring components of the metabolic syndrome. The lack of any components of the metabolic syndrome was demonstrated in $14.78 \%$ of the children aged $10-12$ as well as in $17.38 \%$ of both adolescents aged 13-15 and 17-18 years. One risk factor was most frequently diagnosed in children aged $10-12$ years $(17.89 \%)$ and it was arterial hypertension $(16.08 \%$ of the whole surveyed population). In turn, in the two other age categories of pupils, apart from arterial hypertension the analyses demonstrated also frequent occurrence of increased concentration of triglycerides and abdominal obesity. The co-occurrence of two MS risk factors was observed in $2.33 \%$ of children aged $10-12$ years, in $2.85 \%$ of adolescents aged $13-$ 15 years and in $5.18 \%$ of these aged $17-18$ years. In the case of older girls from age categories: $13-15$ and 17-18 years, two components of the metabolic syndrome occurred slightly more often compared to the younger girls, and also compared to the boys from the same age cat- 
egories. The two most frequent concurrent components of the metabolic syndrome included: excessive waist circumference and increased arterial blood pressure in the youngest group of the surveyed. Three MS components were demonstrated in 15 persons $(2.0 \%$ of the whole surveyed population), including 7 girls and 8 boys. The persons with three MS risk factors from the age category 13 15 years constituted $0.26 \%$ whereas these from the age category $17-18$ years constituted $1.69 \%$ of the surveyed. No persons with three MS risk factors were shown in the age category 10-12 years. In the group of adolescents aged 17-18 years, the most frequent concurrent components of the metabolic syndrome included: increased concentration of triglycerides, reduced concentration of HDL cholesterol fraction in blood serum and excessive waist circumference. In the group aged 13-15 years, the concurrent risk factors included: increased concentration of triglycerides, increased arterial blood pressure and excessive waist circumference.

The statistical analysis of results is presented in Table 4. Significant correlations were demonstrated between gender and age of the surveyed and the fre- quency of co-occurrence of one, two or three MS risk factors in the surveyed children and adolescents.

Physical activity plays one of the key roles in the prophylaxis of cardio-vascular diseases. Diminished participation of adolescents in various forms of physical activity as well as generally decreasing participation in physical activities with age are, however, observed these days. Table 5 summarizes results of the frequency of occurrence of MS components in the studied group depending on the physical activity. A statistically significant correlation was demonstrated in the surveyed group between the number of occurring MS components and physical activity. No risk factors of the metabolic syndrome were observed in over $1 / 3$ of the persons $(33.2 \%)$ declaring high physical activity. The number of persons with equally good health condition but declaring medium physical activity was lower by half $(16.2 \%)$. The concurrence of three risk factors of the metabolic syndrome, irrespective of the intensity of the undertaken physical activity, was determined in the group of boys aged 13-15 years.

Table 5. Frequency of occurrence of metabolic syndrome components in the surveyed groups ( $\mathrm{n}=502)$ depending on physical activity

\begin{tabular}{|c|c|c|c|c|c|c|c|c|c|c|c|}
\hline \multirow{3}{*}{ Gender } & \multirow{3}{*}{ Age category } & \multirow{3}{*}{$\begin{array}{l}\text { Physical } \\
\text { activity }\end{array}$} & \multicolumn{8}{|c|}{ Number of components of the metabolic syndrome } & \multirow{3}{*}{$\mathrm{P}$} \\
\hline & & & \multicolumn{2}{|c|}{0} & \multicolumn{2}{|c|}{1} & \multicolumn{2}{|c|}{2} & \multicolumn{2}{|c|}{3} & \\
\hline & & & $\mathrm{n}$ & $\%$ & $\mathrm{n}$ & $\%$ & $\mathrm{n}$ & $\%$ & $\mathrm{n}$ & $\%$ & \\
\hline \multirow{6}{*}{$\begin{array}{c}\text { Girls } \\
(n=262)\end{array}$} & \multirow{2}{*}{$10-12$ years } & Medium & 25 & 5.0 & 22 & 4.4 & 5 & 1.0 & 0 & 0.0 & \multirow{6}{*}{$<0.0001$} \\
\hline & & High & 47 & 9.4 & 32 & 6.4 & 2 & 0.4 & 0 & 0.0 & \\
\hline & \multirow{2}{*}{$13-15$ years } & Medium & 23 & 4.6 & 17 & 3.3 & 10 & 2.0 & 0 & 0.0 & \\
\hline & & High & 51 & 10.1 & 22 & 4.3 & 6 & 1.2 & 0 & 0.0 & \\
\hline & \multirow{2}{*}{ Girls in total } & Medium & 48 & 9.6 & 39 & 7.8 & 15 & 3.0 & 0 & 0.0 & \\
\hline & & High & 98 & 19.5 & 54 & 10.7 & 8 & 1.6 & 0 & 0.0 & \\
\hline \multirow{6}{*}{$\begin{array}{c}\text { Boys } \\
(n=240)\end{array}$} & \multirow{2}{*}{$10-12$ years } & Medium & 12 & 2.4 & 15 & 3.0 & 7 & 1.4 & 0 & 0.0 & \multirow{6}{*}{$<0.00001$} \\
\hline & & High & 30 & 6.0 & 69 & 13.7 & 4 & 0.8 & 0 & 0.0 & \\
\hline & \multirow{2}{*}{$13-151$ years } & Medium & 21 & 4.2 & 11 & 2.2 & 5 & 1.0 & 1 & 0.2 & \\
\hline & & High & 39 & 7.7 & 24 & 4.8 & 1 & 0.2 & 1 & 0.2 & \\
\hline & \multirow{2}{*}{ Boys in total } & Medium & 33 & 6.6 & 26 & 5.2 & 12 & 2.4 & 1 & 0.2 & \\
\hline & & High & 69 & 13.7 & 93 & 18.5 & 5 & 1.0 & 1 & 0.2 & \\
\hline \multirow{6}{*}{$\begin{array}{c}\text { Total } \\
(\mathrm{n}=502)\end{array}$} & \multirow{2}{*}{$10-121$ years } & Medium & 37 & 7.4 & 37 & 7.4 & 12 & 2.4 & 0 & 0.0 & \multirow{6}{*}{$<0.00001$} \\
\hline & & High & 77 & 15.3 & 101 & 20.1 & 6 & 1.2 & 0 & 0.0 & \\
\hline & \multirow{2}{*}{$13-15$ years } & Medium & 44 & 8.9 & 28 & 5.6 & 15 & 3.0 & 1 & 0.2 & \\
\hline & & High & 90 & 17.9 & 46 & 9.1 & 7 & 1.4 & 1 & 0.2 & \\
\hline & \multirow{2}{*}{$\begin{array}{c}\text { Whole } \\
\text { surveyed group }\end{array}$} & Medium & 81 & 16.2 & 65 & 13.0 & 27 & 5.4 & 1 & 0.2 & \\
\hline & & High & 167 & 33.2 & 147 & 29.2 & 13 & 2.6 & 1 & 0.2 & \\
\hline
\end{tabular}

$\mathrm{p}<0.05$ - the level of significance of $\mathrm{chi}^{2}$ test used to compare the frequency of occurrence of metabolic syndrome components in groups of boys and girls depending on physical activity

The assessment of the effect of physical activity on the frequency of MS risk factors occurrence did not include the surveyed from the age category 17-18 years, as they all declared medium physical activity.
No significant differences were demonstrated in this study between the place of living - large city or areas outside this city - and the frequency of occurrence of MS components in the surveyed groups of children 
and adolescents. This outcome of the statistical analysis of the results could be influenced by relatively low percentage of the surveyed persons living outside the city.

\section{DISCUSSION}

In this study, the frequency of occurrence of the fully-symptomatic metabolic syndrome in children and adolescents was diagnosed based on the concurrence of abdominal obesity and at least two metabolic disorders manifested by increased concentrations of triglycerides and glucose in blood serum and arterial hypertension. These criteria are consistent with IDF guidelines of 2007. In the whole surveyed group (771 persons), the fully-symptomatic metabolic syndrome was diagnosed in 15 subjects, both boys and girls, which constituted $1.95 \%$ of the studied group. They were mainly adolescents aged 17-18 years. Alarming is the fact that the main risk factor of MS - overweight and obesity was demonstrated in over $17 \%$ of all surveyed. Obesity was reported mainly among children aged $10-12$ years and adolescents aged 17-18 years, whereas overweight prevailed among 17-18-year-olds. This points to the maintenance of the incorrect body mass in part of the surveyed children from the early years of their life till the beginning of adulthood, which results in the appearance of severe metabolic disorders in this group at such a young age. From Jenssen et al. [11] research conducted among 5890 people aged 11-16, overweight (before obesity) was disturbed among 15\% (13.9-16.1\%) in relation to the whole group of examined persons, and obesity - in $4.6 \%(4.0-5.2 \%)$. The incidence of overweight and obesity was higher in the examined boys than in girls. However, the prevalence rates of overweight and obesity in the three age categories of children and adolescents did not differ. This study has shown that the lack of physical activity and excessive TV viewing are strongly associated with the prevalence of overweight and obesity in adolescents from Canada. Data from $\mathrm{Eu}-$ rope and North America collected in a review article by Currie et al. [7] indicate that the prevalence of overweight and obesity in 11-year-old girls $(n=18.101$, in 29 countries, year $=2001 / 2002)$ and 15 -year $\mathrm{s}(\mathrm{n}=$ 27.878 , in 34 countries, year $=2005 / 2006$ ) ranges from $4 \%$ to $28 \%$. Many authors whose works were discussed by Fichna et al. [9] emphasize a close correlation between increased frequency of obesity occurrence and increasing number of various metabolic disorders, including the metabolic syndrome, that are revealing in the pubescence period.

Results of investigations addressing the evaluation of the frequency of metabolic syndrome occurrence in children and adolescents are highly divergent. It is mainly due to the adopted diagnostic criteria, age of the surveyed and place of the study. In the NHANES III survey,
De Ferranti et al. [8] adopted very rigorous criteria acc. to ATPIII guidelines. They demonstrated the occurrence of fully symptomatic MS in $9.2 \%$ of American teenagers (12-19 years). In turn, a study by Cook et al. [6] based on determination of excessive waist circumference, increased blood concentrations of triglycerides, HDL cholesterol fraction, and glucose as well as hypertension proved the occurrence of fully-symptomatic MS in $4.2 \%$ of American children and adolescents at the same age. In a study conducted by Castillo et al. [4] in central Mexico on a group of 1366 people aged 7 to 24 years, it was found that about 1 person for every 5 subjects had full MS criteria (19.2\% for women and $20.2 \%$ for men). Only 1 examined person for every 10 was free of any MS component. In the group of subjects, low HDL (85.4\% of the group) was most frequently observed, while excessive waist circumference was observed in $27.9 \%$ of the examined persons. Among children aged 10-14 with a high BMI, about $66 \%$ were positive for MS.

In Polish surveys, the frequency of MS occurrence demonstrated in these age categories was also diversified. Results of investigations conducted by Kolarzyk et al. [12], based on ATP III criteria, showed that the frequency of MS occurrence in schoolchildren reached $11.7 \%$ and that all these children were characterized by visceral obesity. In turn, a study by Białokoz-Kalinowska et al. [3] covered 112 obese teenagers at the age of 10-17 years. The main study inclusion criterion was diagnosed obesity (BMI $\geq 97 . \mathrm{pc}$ ) and simultaneous diagnosis of visceral obesity $>90$.pc being a prerequisite for MS diagnosis according to IDF 2007. The metabolic syndrome was diagnosed in $10.7 \%$ of the surveyed, with its higher frequency noted in the group of boys $(16.6 \%)$ than girls (3.8\%). In a study conducted by Mikołajczak et al. [14] among 778 adolescents (409 girls, 369 boys) aged 16-18 years, the occurrence of metabolic syndrome consisting of 3 or 4 components was revealed in $7.1 \%$ of adolescents. The three comorbid risk factors were abnormal triglycerides, waist circumference and blood pressure $(43.5 \%$ of the group with three components of MS). Przybysz et al. [17] evaluated the frequency of MS occurrence in 106 children: 69 girls and 37 boys aged 6-18 years with simple obesity. The MS recognized based on IDF criteria, likewise in our study, was reported in $5.7 \%$ of the surveyed children. Pyrżak et al. [18] evaluated the frequency of MS occurrence based on criteria applied by Cook, de Ferranti and these recommended by IDF. The study was conducted with 178 patients with simple obesity, including 93 girls and 85 boys, aged 7-18 years. Amongst 122 surveyed subjects over 12 years of age, $51.6 \%$ met MS criteria acc. to Cook, and 67.2\% met MS criteria acc. to de Ferranti. In turn, diagnosis consistent with IDF criteria revealed the occurrence of MS in $34.2 \%$ of the obese subjects aged 10-16 years. Even at the same qualification criteria, the frequency of occurrence of the fully-symptomatic MS 
demonstrated in our study was significantly lower than in the above-cited works. It may be due to different age structure and population number of the surveyed groups of children and adolescents and, thereby, to different frequency of abdominal obesity occurrence. The fact that the children examined in our study originated from schools taking part in the "Network of schools promoting health" program may be the factor which distorts the positive results obtained in the survey. Presumably, owing to multiple health-promoting actions undertaken in these schools, their pupils have gained greater health knowledge and awareness. Nonetheless, demonstration of so complex metabolic disorders typical of the MS even in such a small group of young persons is a very poor prognostics of both their life span and life quality.

Our survey demonstrated a statistically significant correlation between the number of occurring MS components and physical activity. No risk factors of the metabolic syndrome were demonstrated in $33.2 \%$ of the surveyed declaring high physical activity. The outcomes of low physical activity, likewise ill-balanced diet, include increased incidence of overweight and obesity already in the early period of life. Stankiewicz et al. [19] observed that children from older age groups were spending more time in front of computer or TV screens, which resulted in their lower physical activity. A study by Chabros et al. [5] demonstrated that children aged 11-13 years more frequently participated in after-school sports activities than the 14-15-year-olds. The number of boys participating in such activities was decreasing statistically significantly with age.

\section{CONCLUSIONS}

In summary, it shall be concluded that the frequency of occurrence of the fully symptomatic MS depended significantly on the age and physical activity of the surveyed and did not depend on their gender. Among the three components of MS, the most frequently detected disorders included: arterial hypertension, abdominal obesity and increased concentration of triglycerides in blood serum.

\section{Acknowledgement}

The study was conducted under the Polish Scientific Research Committee (KBN) grant no. 312183438 entitled "Evaluation of the frequency of occurrence of dietary and non-dietary risk factors of the metabolic syndrome in girls and boys at various stages of their pubescence".

\section{Conflict of interest}

The authors declare no conflict of interest.

\section{REFERENCES}

1. Alberti K.G., Zimmet P., Shaw J.: Metabolic syndrome a new world - wide definition. A Consensus Statement from the International Diabetes Federation. Diabet Med 2006; 23(5): 469-480 doi: 10.1111/j.1464-5491.2006.01858.x.

2. Al-Hamad D., Raman V: Metabolic syndrome in children and adolescents. Transl Pediatr 2017; 6(4): 397407 doi: 10.21037/tp.2017.10.02.

3. Białkoz-Kalinowska I., Zapolska J., PiotrowskaJastrzębska J.: Zespół metaboliczny u dzieci doświadczenia własne [Metabolic syndrome in children and adolescents - in own clinical observation]. Pediatr Med Rodzin 2009; 5(4): 254-258 (in Polish).

4. Castillo E.H., Borges G., Talavera J.O., et al.: Body Mass Index and the Prevalence of Metabolic Syndrome among Children and Adolescents in Two Mexican Populations. J Adolesc Health 2007; 40(6): 521-526 doi: 10.1016/j.jadohealth.2006.12.015.

5. Chabros E., Charzewska J., Rogalska-Niedźwiedź M, et al.: Mała aktywność fizyczna młodzieży w wieku pokwitania sprzyja rozwojowi otyłości [Low physical activity of adolescent promotes development of obesity]. Probl Hig Epidemiol 2008; 89(1): 58-61 (in Polish).

6. Cook S., Weitzman M., Auinger P., et al.: Prevalence of metabolic syndrome phenotype in adolescents. Archiv Pediatr Adolesc Med 2003; 157(8): 821-827 doi: 10.1001/archpedi.157.8.821.

7. Currie C., Ahluwalia N., Godeau E., et al.: Is Obesity at Individual and National Level Associated With Lower Age at Menarche? Evidence From 34 Countries in the Health Behaviour in School-aged Children Study. J Adolesc Health 2012; 50(6): 621-626 doi: 10.1016/j. jadohealth.2011.10.254.

8. De Ferranti A., Gauyreau K., Ludwig D., et al.: Prevalence of metabolic syndrome in America Adolescents. Findings from the Third National Health and Nutrition Examination Survey. Circulation 2004; 110(16): 24942497; doi: 10.1161/01.CIR.0000145117.40114.C7.

9. Fichna P., Skowrońska B.: Otyłość oraz zespół metaboliczny u dzieci i młodzieży [Obesity and metabolic syndrome in children and youth]. Fam Med Prim Care Rev 2008; 10(2): 269-278 (in Polish).

10. Friend A., Craig L., Turner S.: The Prevalence of Metabolic Syndrome in Children: A Systematic Review of the Literature. Metab Syndr Relat Disord 2013; 11(2): 71-80 doi: 10.1089/met.2012.0122.

11. Janssen I., Katzmarzk P.T., Boyce W.F., et al.: Overweight and Obesity in Canadian Adolescents and their Associations with Dietary Habits and Physical Activity Patterns. J Adolesc Health 2004; 35(5): 360-367 doi: 10.1016/j.jadohealth.2003.11.095.

12. Kolarzyk E., Janik A., Kwiatkowski J.: Ocena ryzyka zespołu metabolicznego u dzieci z nadwagą i otyłością. Cz. 1. Antropometryczne i biochemiczne wskaźniki ryzyka zespołu metabolicznego [Evaluation of the risk of metabolic syndrome among overweight and obese children. Part I. Anthropometric and biochemical factors of the risk of metabolic syndrome development]. Probl Hig Epidemio. 2011; 92(4): 741-746 (in Polish). 
13. Kułaga Z., Różdżýska A., Palczewska I., et al.: Siatki centylowe wysokości, masy ciała i wskaźnika masy ciała dzieci i młodzieży w Polsce - wyniki badania OLAF [Percentile charts of height, body mass and body mass index in children and adolescents in Poland - results of the OLAF study]. Stand Med Pediatr 2010; 7: 690-700 (in Polish).

14. Mikołajczak J., Piotrowska E., Biernat J., et al.: Ocena czynników ryzyka zespołu metabolicznego u dziewcząt i chłopców $z$ terenu południowo-zachodniej części Polski [Assessment of risk factors of metabolic syndrome in girls and boys from South-West area of Poland]. Rocz Panstw Zakl Hig 2011; 62(1): 83-92 (in Polish).

15. Niemirowska A., Litwin M.: Definicja zespołu metabolicznego u dzieci i młodzieży [Definition of metabolic syndrome in children and adolescents]. Stand Med Pediatr 2008; 5: 117-123 (in Polish).

16. Pergher N.Q.R, De Melo M.E., Halpern A., et al.: Is a diagnosis of metabolic syndrome applicable to children? J Pediatr 2010; 86(2): 101-108 doi: 10.2223/jped.1983.

17. Przybysz M., Rymaszewska-Syryca D., Nastaj M., et $a l .:$ Ocena częstości występowania zespołu metabolicznego u dzieci z otyłością prostą [The Prevalence of Metabolic Syndrome in Children with Oobesity]. Endokrynol Pediatr 2009; 2(27): 45-53 doi: 10.18544/EP01.08.02.1145 (in Polish).

18. Pyrżak B., Majcher A., Rumińska M., et al.: Analiza częstości występowania zespołu metabolicznego z zas- tosowaniem kryteriów Cook'a, de Ferranti i IDF u dzieci z otyłością [The Prevalence of Metabolic Syndrome According Cook, de Ferranti and IDF Criteria in Children with Obesity]. Endokrynol Pediatr 2008; 2(23): 21-32 doi: 10.18544/EP-01.07.02.0931 (in Polish).

19. Stankiewicz M., Pieszko M., Śliwińska A., et al.: Występowanie nadwagi i otyłości oraz wiedza i zachowania zdrowotne dzieci i młodzieży małych miast i wsi - wyniki badania Polskiego Projektu 400 miast [Obesity, knowledge of diet and healthy behaviors in children and adolescents from small towns and villages - results of Polish Project of 400 Cities]. Endokrynol Otył Zab Przem Mat 2010; 6(2): 59-68 (in Polish).

20. Szadkowska A.: Zespół metaboliczny u dzieci i młodzieży [Metabolic syndrome in children and adolescents]. Przeg Pediatr 2009; 39(3): 161-167 (in Polish).

21. Wilk B.: Pomiar ciśnienia tętniczego krwi na podstawie automatycznej detekcji tonów Korotkowa [Arterial blood pressure measurement based on automatic detection of Korotkoff sounds]. Prz. Elektrotech. 2012; 88(10b): 17-20 (in Polish).

22. Zimmet P., Alberti G., Kaufman F., et al.: The metabolic syndrome in children adolescents: the IDF consensus. Diabet Voice 2007; 8(5): 299-306 doi: 10.1111/j.13995448.2007.00271.x.

Received: 23.01.2020

Accepted: 17.02.2020 